\title{
Car Wash Wastewater Treatment Using an Advanced Oxidation Process: A Rapid Technique for the COD Reduction of Water Pollutant Sources
}

\author{
Reza Davarnejad*, Kasra Sarvmeili, Meysam Sabzehei \\ Department of Chemical Engineering, Faculty of Engineering, Arak University, Arak 38156-8-8349, Iran.
}

*Corresponding author: Reza Davarnejad, e-mail: R-Davarnejad@araku.ac.ir Tel.: +98-9188621773 Fax: + 98-86-34173450

Received Febraury 19 ${ }^{\text {th }}, 2019$; Accepted August 25 th $^{\text {}} 2019$.

DOI: http://dx.doi.org/10.29356/jmcs.v63i4.786

\begin{abstract}
In this paper, a car wash wastewater (CW) was treated by an economic and eco-friendly method called electro-Fenton (EF) technique. The experiments were conducted to investigate the effect of five important variables including reaction time, current density, $\mathrm{pH}, \mathrm{H}_{2} \mathrm{O}_{2} / \mathrm{Fe}^{2+}$ molar ratio and $\mathrm{H}_{2} \mathrm{O}_{2} / \mathrm{Car}$ wash wastewater $(\mathrm{mL} / \mathrm{L})$ on the quality characteristics of wastewater such as COD, BOD 5 , TOC, TSS, heavy metals, EC, surfactants and hardness. By applying Box-Behnken design (BBD) and response surface methodology (RSM), the optimum operating conditions were obtained. The optimum conditions for COD [as a main factor in a wastewater (according to the environmental protocols)] removal of $68.72 \%$ were experimentally found at reaction time of $75.80 \mathrm{~min}$, current density of $58.81 \mathrm{~mA} / \mathrm{cm}^{2}, \mathrm{pH}$ of 3.02 , volume ratio of $\mathrm{H}_{2} \mathrm{O}_{2} / \mathrm{CW}$ of 1.62 $\mathrm{mL} / \mathrm{L}, \mathrm{H}_{2} \mathrm{O}_{2} / \mathrm{Fe}^{2+}$ molar ratio of 3.66 .

Keywords: Car wash wastewater; electro-fenton; optimization; water quality.

Resumen. En este artículo se trató un agua residual de "car wash" $(\mathrm{CW})$ con un método amigable con el medioambiente denominado electro-Fenton. Los experimentos fueron realizados para investigar el evecto de cinco variables importantes incluyendo el tiempo de reacción, la densidad de corriente, $\mathrm{pH}$, la relación molar $\mathrm{H}_{2} \mathrm{O}_{2} / \mathrm{Fe}^{2+}$ y la relación $\mathrm{H}_{2} \mathrm{O}_{2}$ /agua residual de "car wash" $(\mathrm{mL} / \mathrm{L}$ ) sobre la calidad del agua residual, tales como DQO, DBO, COT, SST, metales pesados, conductividad eléctrica, surfactantes y dureza. Aplicando un diseño "Box-Behnken" (BBD) y la metodología de la superficie de respuesta (RSM por sus siglas en inglés), se determinaron las condiciones de operación optimizadas. Las condiciones optimizadas para DQO (como factro principal medido en el agua y siguiendo protocolos estandarizados) se logra remover el $68.72 \%$ a un tiempo de reacción de $75.80 \mathrm{~min}$, con una densidad de corriente de $58.81 \mathrm{~mA} / \mathrm{cm}^{2}, \mathrm{pH} 3.02, \mathrm{H}_{2} \mathrm{O}_{2} / \mathrm{CW}$ de $1.62 \mathrm{~mL} / \mathrm{L}$ y $\mathrm{H}_{2} \mathrm{O}_{2} / \mathrm{Fe}^{2+}$ de 3.66.
\end{abstract}

Palabras clave: Agua residual de "car wash"; electro-fenton; optimización calidad de agua.

\section{Introduction}

During the last century, water consumption has widely grown with increasing population growth. Around the world, a significant amount of wastewater is discharged daily into rivers, lakes, and oceans [1-3]. In the developed countries, the industries are the largest consumers of water, while in the developing countries, the agricultural sector is the largest consumer of water [4]. Industrial wastewater, leads to environmental 
problems and threatens the health of humans, due to its toxic nature, including organic compounds and heavy metals [5-7].

Car wash stations enter a large amount of contaminated wastewater into a municipal sewage cycle [8]. This wastewater contains pollutants such as detergents, grease, oils, heavy metals and organic matter which increase the amount of Biological Oxygen Demand (BOD) and Chemical Oxygen Demand (COD) in the wastewater [9]. Therefore, the treatment of this wastewater is necessary before entering urban sewage. Furthermore, the return of water from wastewater treatment to the consumption cycle reduces water consumption during the washing process at the car wash.

Various methods such as flocculation [9], membrane filtration [10], adsorption [10], biological treatment [9] and chemical oxidation [11] have been used for the treatment of car wash wastewaters(CW). The limitations in these processes and operations can be eliminated by the use of alternative methods. In the recent years, Advanced Oxidation Processes (AOP) have attracted the attention of researchers [12]. These AOPs operate on the basis of the production of oxidants such as hydroxyl radical. Hydroxyl radical is able to decompose organic pollutants during a short and non-selective contact [13-15]. In the end, organic matter decomposes into non-toxic compounds such as water and carbon dioxide when exposed to hydroxyl [16-18]. The most commonly used AOP is the Fenton process. In the Fenton reaction and in acidic conditions, electron transfer between ferrous ions $(\mathrm{Fe} 2+)$ and $\mathrm{H}_{2} \mathrm{O}_{2}$ leads to hydroxyl radical production (Eq. 1) which plays a main role in reducing COD $[19,20]$ :

$$
\mathrm{Fe}^{2+}+\mathrm{H}_{2} \mathrm{O}_{2} \rightarrow \mathrm{Fe}^{3+}+\mathrm{OH}^{\circ}+\mathrm{OH}^{-}
$$

Electrochemical Advanced Oxidation Processes (EAOP) can use electricity to produce hydroxyl radical [21]. The most popular process among EAOPs is the electro-Fenton (EF) process because it uses electricity as an eco-friendly source of energy. Cost-effectiveness and simplicity of operation are the other advantages to make EF suitable for wastewater treatment [22,23]. The EF process which is a combination of Fenton and electro-coagulation processes has a high impact in treating hazardous and organic pollutants [24]. In this process with in situ production of hydroxyl radical as the second most powerful oxidizing species $\left(\mathrm{E}^{\circ}=2.8 \mathrm{~V}\right)$ is able to oxidize organic pollutants to inorganic ones (Eqs. 2 and 3$)$.

$$
\begin{aligned}
& \mathrm{OH}^{\circ}+\text { Organic pollutants } \rightarrow \text { Primary intermediates } \\
& \text { Primary intermediates }+\mathrm{OH}^{\circ} \rightarrow \mathrm{CO}_{2}+\mathrm{H}_{2} \mathrm{O}+\text { inorganic ions }
\end{aligned}
$$

So, an EF process was employed for the treatment of a real CW. The effect of main independent variables [such as reaction time, current density, $\mathrm{pH}, \mathrm{H}_{2} \mathrm{O}_{2} / \mathrm{Fe} 2+$ molar ratio and volume ratio of $\mathrm{H}_{2} \mathrm{O}_{2} / \mathrm{CW}$ $(\mathrm{mL} / \mathrm{L})$ ] was studied on Chemical Oxygen Demand (COD), Biological Oxygen Demand (BOD5), Total Organic Carbon (TOC), Total Suspended Solids (TSS), heavy metals, Electrical Conductivity (EC), surfactants and hardness (as water quality parameters) removal from $\mathrm{CW}$ using iron electrodes. A statistical method was used to optimize these parameters [25]. In order to maximize COD and the other water quality parameters removal, Box-Behnken design (BBD) and response surface methodology (RSM) were used to design the experiments and optimize the operating conditions [26]. In fact, the electro-Fenton process can be applied when there are large amounts of COD in wastewater and BOD5/COD ratio is less than one [24]. Furthermore, a car wash wastewater is containing huge amounts of sands and suspended solids which assist the electro-Fenton process that is based on the flocculation and coagulation. 


\section{Experimental}

\section{Materials and methods \\ Wastewater sampling and characteristics}

The wastewater used in this study was collected from a local car wash station (Sadaf Car wash, Malayer, Iran). The samples were collected over a week (9-11 a.m. of every day). $20 \mathrm{~L}$ of the car wash station was prepared and stored in a plastic container. The container was transported to Arak University Chemical Engineering Research Lab and stored at $4{ }^{\circ} \mathrm{C}$ before further analysis. According to the analysis done by the Oil Industry Health Center on this wastewater, the initial quality characteristics of wastewater were reported in Table 1. The $\mathrm{pH}$ can be adjusted by $0.1 \mathrm{M} \mathrm{H}_{2} \mathrm{SO}_{4}$ and $0.1 \mathrm{M} \mathrm{NaOH}$ (supplied by Merck Co., Quebec, Canada) for each experiment. Since the wastewater cannot pass the environmental protocol, it should be treated. Moreover, BOD5/COD ratio is less than $1(\approx 0.34)$. Therefore, the EF process as a rapid, easy and efficient one is suggested [28].

Table 1. Initial quality characteristics of wastewater.

\begin{tabular}{|c|c|c|}
\hline Water quality parameter & Unit & Value \\
\hline COD & $\mathrm{mg} / \mathrm{L}$ & 460 \\
\hline BOD $_{5}$ & $\mathrm{mg} / \mathrm{L}$ & 155 \\
\hline TOC & $\mathrm{mg} / \mathrm{L}$ & 170 \\
\hline TSS & $\mathrm{mg} / \mathrm{L}$ & 350 \\
\hline Heavy metals & $\mathrm{mg} / \mathrm{L}$ & 366 \\
\hline $\mathrm{pH}$ & & 7.6 \\
\hline $\mathrm{EC}$ & $\mu \mathrm{s} / \mathrm{cm}$ & 604 \\
\hline Surfactants & $\mu \mathrm{g} / \mathrm{L}$ & 458 \\
\hline Hardness & $\mathrm{mg} / \mathrm{L}$ & 740 \\
\hline
\end{tabular}

\section{Experimental set-up}

The experimental set-up main parts are DC power supply, digital magnetic mixer, $400 \mathrm{~mL}$ cell as the reactor and two parallel plate iron electrodes in a rectangular shape with total surface of $1 \mathrm{~cm}^{2}$, where the spacing between them was $3 \mathrm{~cm}$ (Fig. 1). In each run, $150 \mathrm{~cm}^{3}$ of CW was taken and its $\mathrm{pH}$ was measured using a pH meter (METTLER-TOLEDO 320, Ohio, US). The $\mathrm{pH}$ meter was calibrated with the standard buffers kit (supplied by Merck Co.) at the room temperature $\left(25 \pm 2{ }^{\circ} \mathrm{C}\right)$ before each analysis. A desired amount of ferrous salt $\left(\mathrm{FeSO}_{4} \cdot \mathrm{H}_{2} \mathrm{O}\right)$ and hydrogen peroxide $\left(\mathrm{H}_{2} \mathrm{O}_{2}\right)$ were added to the cell before turning on the DC power supply.

Then, the electrodes were connected to a constant potential difference that was provided from a DC power supply ( $30 \mathrm{~V}$ and $10 \mathrm{~A}$ ). The stirrer speed was fixed at $400 \mathrm{rpm}$ (without observing vortex formation). All experiments were carried out at room temperature $\left(25 \pm 2{ }^{\circ} \mathrm{C}\right)$ and atmospheric pressure.

The power source was turned off when the reaction time was obtained. Then, the solution was left around $30 \mathrm{~min}$ for sedimentation of suspended solids. After each run, the electrodes were cleaned with distilled water to remove any sludge residues on the surfaces. Then, the sample was placed in a calibrated UV-Vis spectrophotometer (HACH, US) and analyzed in terms of COD at wavelength of $276 \mathrm{~nm}$ [28]. For the other water quality parameters, all samples were sent to Reliable Environmental Lab of Arak city and they were carefully analyzed (in terms of each water quality parameter) by special techniques and devices. 

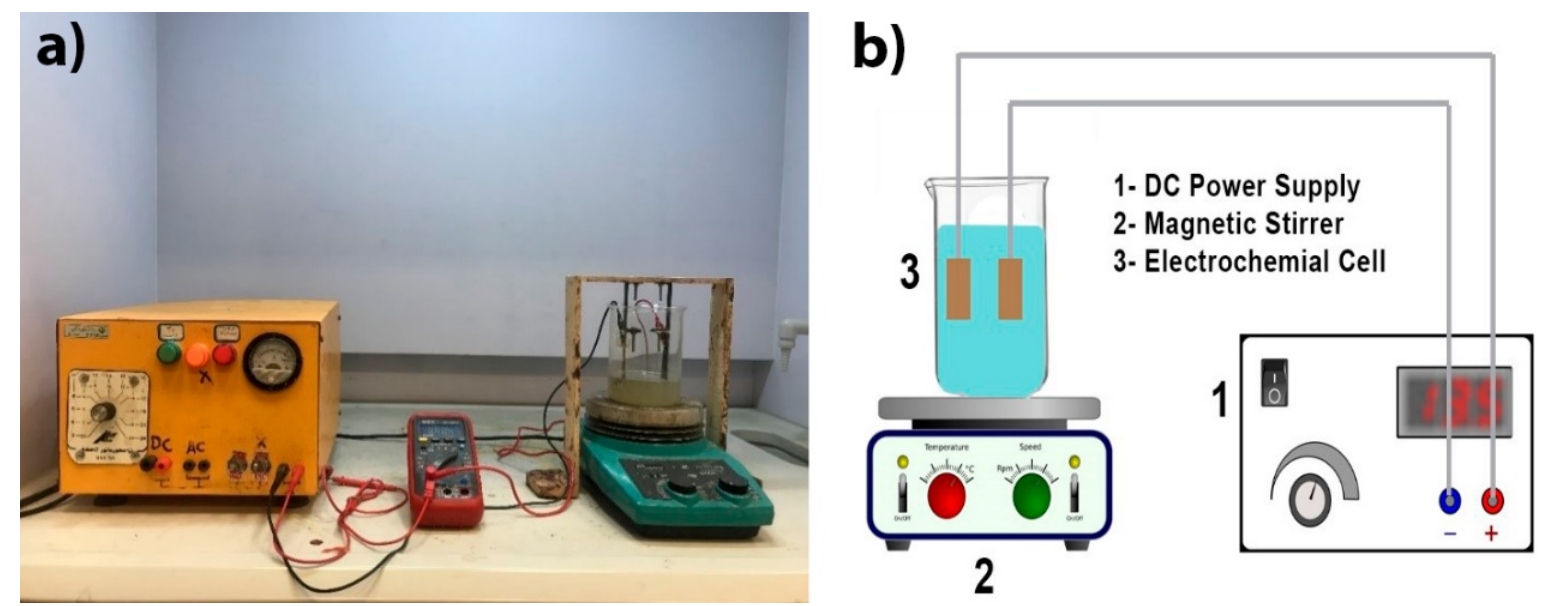

Fig 1. (a) EF apparatus, (b) EF schematic diagram

\section{Design of experiments}

The Design Expert software (version 10.0.0) was applied for the experiments design. As shown in Table 2 five independent variables including reaction time $\left(\mathrm{X}_{1}\right)$, current density $\left(\mathrm{X}_{2}\right), \mathrm{pH}\left(\mathrm{X}_{3}\right)$, volume ratio of $\mathrm{H}_{2} \mathrm{O}_{2} / \mathrm{CW} \mathrm{mL} / \mathrm{L}\left(\mathrm{X}_{4}\right)$ and $\mathrm{H}_{2} \mathrm{O}_{2} / \mathrm{Fe}^{2+}$ molar ratio $\left(\mathrm{X}_{5}\right)$ with three level full factorial Box-Behnken response surface experimental designs were used. Therefore, forty seven experiments were designed [27, 28]. The goal of this study was to find the optimized operating conditions for maximizing the COD removal percentage (Y\%) as a main factor in the water quality consideration.

Table 2. Independent variables and their levels

\begin{tabular}{|c|c|c|c|c|}
\hline Variable & \multirow{2}{*}{ Factor } & \multicolumn{3}{|c|}{ Coded factors } \\
\cline { 3 - 5 } & & $\mathbf{- 1}$ & $\mathbf{0}$ & $+\mathbf{1}$ \\
\hline Reaction time (min) & $\mathrm{X}_{1}$ & 15 & 50 & 85 \\
\hline Current density $\left(\mathrm{mA} / \mathrm{cm}^{2}\right)$ & $\mathrm{X}_{2}$ & 20 & 50 & 80 \\
\hline $\mathrm{pH}$ & $\mathrm{X}_{3}$ & 2 & 3.5 & 5 \\
\hline $\mathrm{H}_{2} \mathrm{O}_{2} /$ wastewater $(\mathrm{mL} / \mathrm{L})$ & $\mathrm{X}_{4}$ & 0.3 & 1.4 & 2.5 \\
\hline $\mathrm{H}_{2} \mathrm{O}_{2} / \mathrm{Fe}^{2+}$ & $\mathrm{X}_{5}$ & 0.5 & 2.75 & 5 \\
\hline
\end{tabular}

Removal percentage calculated by the following equation:

$$
Y(\%)=\frac{c_{i}-c_{0}}{c_{i}} \times 100
$$

where, $\mathrm{C}_{\mathrm{i}}$ and $\mathrm{C}_{0}$ are initial and final concentrations, respectively. Table 3 shows experimental matrix design obtained by the software. 
Table 3. Experimental matrix design and COD data

\begin{tabular}{|c|c|c|c|c|c|c|c|}
\hline \multirow[t]{2}{*}{ Run } & \multirow{2}{*}{$\begin{array}{c}\text { Reaction } \\
\text { time (min) }\end{array}$} & \multirow{2}{*}{$\begin{array}{l}\text { Current density } \\
\left(\mathrm{mA} / \mathrm{cm}^{2}\right)\end{array}$} & \multirow[t]{2}{*}{ pH } & \multirow{2}{*}{$\begin{array}{c}\mathrm{H}_{2} \mathrm{O}_{2} / \text { wastewater } \\
(\mathrm{mL} / \mathrm{L})\end{array}$} & \multirow{2}{*}{$\begin{array}{c}\mathrm{H}_{2} \mathrm{O}_{2} / \mathrm{Fe}^{2+} \\
\text { molar ratio }\end{array}$} & \multicolumn{2}{|c|}{ COD Removal (\%) } \\
\hline & & & & & & Predicted & Actual \\
\hline 1 & -1 & +1 & -1 & -1 & -1 & 24.31 & 24.84 \\
\hline 2 & +1 & +1 & +1 & -1 & +1 & 36.09 & 36.10 \\
\hline 3 & +1 & -1 & -1 & -1 & +1 & 32.79 & 33.40 \\
\hline 4 & 0 & 0 & +1 & 0 & 0 & 52.66 & 53.16 \\
\hline 5 & -1 & +1 & +1 & -1 & +1 & 20.06 & 20.32 \\
\hline 6 & -1 & 0 & 0 & 0 & 0 & 51.0 & 50.23 \\
\hline 7 & +1 & +1 & -1 & -1 & +1 & 47.94 & 48.31 \\
\hline 8 & -1 & -1 & +1 & +1 & -1 & 17.28 & 17.83 \\
\hline 9 & -1 & +1 & +1 & +1 & -1 & 34.27 & 33.95 \\
\hline 10 & 0 & 0 & 0 & +1 & 0 & 59.41 & 59.25 \\
\hline 11 & -1 & -1 & +1 & +1 & +1 & 16.11 & 16.83 \\
\hline 12 & 0 & 0 & 0 & 0 & 0 & 63.26 & 63.15 \\
\hline 13 & +1 & +1 & -1 & +1 & +1 & 57.43 & 56.71 \\
\hline 14 & -1 & +1 & +1 & +1 & -1 & 22.00 & 22.31 \\
\hline 15 & -1 & +1 & +1 & +1 & +1 & 26.28 & 25.20 \\
\hline 16 & +1 & +1 & +1 & -1 & -1 & 27.96 & 27.70 \\
\hline 17 & 0 & 0 & 0 & 0 & 0 & 63.26 & 63.85 \\
\hline 18 & +1 & +1 & -1 & +1 & -1 & 43.35 & 43.98 \\
\hline 19 & -1 & -1 & -1 & +1 & -1 & 20.65 & 19.75 \\
\hline 20 & -1 & +1 & +1 & -1 & -1 & 18.12 & 18.25 \\
\hline 21 & 0 & +1 & 0 & 0 & 0 & 59.53 & 59.60 \\
\hline 22 & -1 & -1 & -1 & +1 & +1 & 23.10 & 23.53 \\
\hline 23 & +1 & -1 & +1 & -1 & +1 & 24.59 & 23.87 \\
\hline 24 & 0 & 0 & 0 & 0 & 0 & 63.26 & 63.98 \\
\hline 25 & 0 & 0 & -1 & 0 & 0 & 60.28 & 59.23 \\
\hline 26 & -1 & +1 & -1 & +1 & -1 & 29.03 & 28.93 \\
\hline 27 & +1 & -1 & +1 & +1 & -1 & 28.12 & 27.53 \\
\hline 28 & +1 & -1 & -1 & +1 & +1 & 42.18 & 41.98 \\
\hline 29 & 0 & 0 & 0 & 0 & -1 & 52.99 & 52.37 \\
\hline 30 & 0 & 0 & 0 & 0 & 0 & 63.26 & 64.05 \\
\hline 31 & 0 & 0 & 0 & -1 & 0 & 52.77 & 52.38 \\
\hline 32 & 0 & 0 & 0 & 0 & 0 & 63.26 & 63.48 \\
\hline 33 & 0 & -1 & 0 & 0 & 0 & 49.60 & 48.98 \\
\hline 34 & -1 & -1 & +1 & -1 & +1 & 10.00 & 10.28 \\
\hline 35 & +1 & 0 & 0 & 0 & 0 & 65.95 & 66.67 \\
\hline 36 & +1 & -1 & +1 & +1 & +1 & 33.14 & 32.71 \\
\hline 37 & +1 & +1 & -1 & -1 & -1 & 36.19 & 35.41 \\
\hline 38 & -1 & -1 & +1 & -1 & -1 & 13.50 & 12.59 \\
\hline 39 & +1 & -1 & -1 & +1 & -1 & 33.54 & 34.20 \\
\hline 40 & +1 & -1 & +1 & -1 & -1 & 21.91 & 22.93 \\
\hline 41 & -1 & -1 & -1 & -1 & -1 & 16.03 & 17.23 \\
\hline 42 & -1 & +1 & -1 & +1 & +1 & 36.93 & 37.58 \\
\hline 43 & -1 & -1 & -1 & -1 & +1 & 16.14 & 15.58 \\
\hline 44 & -1 & +1 & -1 & -1 & +1 & 29.87 & 29.63 \\
\hline 45 & +1 & +1 & +1 & +1 & +1 & 44.74 & 45.27 \\
\hline 46 & 0 & 0 & 0 & 0 & +1 & 58.28 & 58.35 \\
\hline 47 & +1 & -1 & -1 & -1 & -1 & 26.49 & 25.93 \\
\hline
\end{tabular}




\section{Results and discussion}

\section{Regression model based on ANOVA and testing}

In this paper, correlations between the response function $(\mathrm{Y})$ and the independent variables were obtained by the following second-order quadratic polynomial model [29]:

$$
Y=\beta_{0}+\sum_{j=1}^{k} \beta_{j} x_{j}+\sum_{i<j} \beta_{i j} x_{i} x_{j}+\sum_{j=1}^{k} \beta_{j j} x_{j}^{2}+\epsilon
$$

where, $\mathrm{Y}$ is the response. $\beta_{0}$ is a constant coefficient. $\beta_{\mathrm{j}}, \beta_{\mathrm{ij}}$ and $\beta_{\mathrm{jj}}$ are the coefficients for the linear, quadratic and interaction effects, respectively. $X_{i}$ and $X_{j}$ are the coded levels for the independent variables. $K$ is the number of independent variables and $\varepsilon$ is the random error.

The following equation presents the BBD model for COD removal percentage obtained from the software. In fact, it shows the relation between all responses and operating variables.

$$
\begin{aligned}
& \operatorname{COD}(\%)=63.26+7.23 X_{1}+4.97 X_{2}-3.81 X_{3}+3.32 X_{4}+2.64 X_{5}+ \\
& 0.36 X_{1} X_{2}-0.51 X_{1} X_{3}+0.61 X_{1} X_{4}+1.55 X_{1} X_{5}-0.91 X_{2} X_{3}+ \\
& 0.26 X_{2} X_{4}+1.36 X_{2} X_{5}-0.21 X_{3} X_{4}-0.90 X_{3} X_{5}+0.59 X_{4} X_{5}- \\
& 4.54 X_{1}^{2}-8.70 X_{2}^{2}-6.79 X_{3}^{2}-7.17 X_{4}^{2}-7.63 X_{5}^{2}
\end{aligned}
$$

where, $\mathrm{X}_{1}, \mathrm{X}_{2}, \mathrm{X}_{3}, \mathrm{X}_{4}$ and $\mathrm{X}_{5}$ are reaction time ( $\left.\mathrm{min}\right)$, $\mathrm{pH}$, current density $\left(\mathrm{mA} / \mathrm{cm}^{2}\right), \mathrm{H}_{2} \mathrm{O}_{2} /$ wastewater volume ratio and $\mathrm{H}_{2} \mathrm{O}_{2} / \mathrm{Fe}^{2+}$ molar ratio, respectively. The experimental and predicted data (obtained from Eq. 6) for COD are shown in Table 3, as well.

\section{ANOVA analysis}

Table 4 shows analysis of variance (ANOVA) for response surface quadratic model terms for COD removal. They will be significant when Prob $>\mathrm{F}$ values are less than 0.05 . A model can properly predict the response when $\mathrm{R}^{2}$ is close to one. Therefore, $\mathrm{X}_{1}, \mathrm{X}_{2}, \mathrm{X}_{3}, \mathrm{X}_{4}, \mathrm{X}_{5}, \mathrm{X}_{1} \mathrm{X}_{2}, \mathrm{X}_{1} \mathrm{X}_{4}, \mathrm{X}_{2} \mathrm{X}_{3}, \mathrm{X}_{2} \mathrm{X}_{4}, \mathrm{X}_{2} \mathrm{X}_{5}, \mathrm{X}_{3} \mathrm{X}_{4}, \mathrm{X}_{4} \mathrm{X}_{5}$, $\mathrm{X}_{1}^{2}, \mathrm{X}_{2}^{2}, \mathrm{X}_{3}^{2}, \mathrm{X}_{4}^{2}, \mathrm{X}_{5}^{2}$ terms for COD removal were significant and non-negligible terms. There is a good agreement between the predicted data and the experimental ones since the $\mathrm{R}^{2}$ equals to 0.9987 for COD. As the $\mathrm{R}^{2}, \mathrm{R}^{2}$ adjusted, $\mathrm{R}^{2}$ predicted amounts are close to one, it can be concluded that regression model is appropriate for this research as illustrated in Table 5 [30].

Table 4. Analysis of variance for response surface quadratic model terms for COD removal.

\begin{tabular}{|l|l|l|l|l|l|}
\hline Source & $\begin{array}{l}\text { Sum of } \\
\text { Squares }\end{array}$ & DF & $\begin{array}{l}\text { Mean } \\
\text { Square }\end{array}$ & F-Value & Prob $>$ F \\
\hline Model & 13426.70 & 20 & 671.33 & 972.85 & $<0.0001$ \\
\hline A & 1776.12 & 1 & 1776.12 & 2573.83 & $<0.0001$ \\
\hline B & 839.43 & 1 & 839.43 & 1216.45 & $<0.0001$ \\
\hline C & 492.41 & 1 & 492.41 & 713.56 & $<0.0001$ \\
\hline D & 374.16 & 1 & 374.16 & 542.21 & $<0.0001$ \\
\hline E & 237.81 & 1 & 237.81 & 344.62 & $<0.0001$ \\
\hline AB & 4.09 & 1 & 4.09 & 5.93 & 0.0221 \\
\hline AC & 8.41 & 1 & 8.41 & 12.18 & 0.0017 \\
\hline AD & 11.81 & 1 & 11.81 & 17.11 & 0.0003 \\
\hline AE & 76.57 & 1 & 76.57 & 110.96 & $<0.0001$ \\
\hline BC & 26.75 & 1 & 26.75 & 38.77 & $<0.0001$ \\
\hline
\end{tabular}




\begin{tabular}{|l|l|l|l|l|l|}
\hline BD & 0.021 & 1 & 0.021 & 0.030 & 0.8628 \\
\hline $\mathbf{B E}$ & 59.30 & 1 & 59.30 & 85.93 & $<0.0001$ \\
\hline $\mathbf{C D}$ & 1.42 & 1 & 1.42 & 2.06 & 0.1634 \\
\hline $\mathbf{C E}$ & 26.21 & 1 & 26.21 & 37.98 & $<0.0001$ \\
\hline $\mathbf{D E}$ & 10.95 & 1 & 10.95 & 15.87 & 0.0005 \\
\hline $\mathbf{A}^{\mathbf{2}}$ & 50.79 & 1 & 50.79 & 73.60 & $<0.0001$ \\
\hline $\mathbf{B}^{\mathbf{2}}$ & 186.66 & 1 & 186.66 & 270.50 & $<0.0001$ \\
\hline $\mathbf{C}^{\mathbf{2}}$ & 113.84 & 1 & 113.84 & 164.97 & $<0.0001$ \\
\hline $\mathbf{D}^{\mathbf{2}}$ & 126.94 & 1 & 126.94 & 183.95 & $<0.0001$ \\
\hline $\mathbf{E}^{\mathbf{2}}$ & 143.55 & 1 & 143.55 & 208.03 & $<0.0001$ \\
\hline Residual & 17.94 & 26 & 0.69 & & \\
\hline Lack of Fit & 17.37 & 22 & 0.79 & 5.50 & 0.0546 \\
\hline Pure Error & 0.57 & 4 & 0.14 & & \\
\hline Cor Total & 13444.64 & 46 & & & \\
\hline
\end{tabular}

Table 5. Quadratic model ANOVA result for COD removal.

\begin{tabular}{|c|c|}
\hline Variable & COD Removal \\
\hline Standard Deviation & 0.83 \\
\hline Mean & 38.07 \\
\hline $\mathrm{R}^{2}$ & 0.9987 \\
\hline $\mathrm{R}^{2}$ adjusted & 0.9976 \\
\hline $\mathrm{R}^{2}$ predicted & 0.9952 \\
\hline Coefficient of variance (C.V) & 2.18 \\
\hline Press & 64.74 \\
\hline Adequate precision & 100.773 \\
\hline
\end{tabular}

The ANOVA for COD showed that F-value is 972.85 for the quadratic model. Furthermore, the large F-value indicates that the most of variation in the response can be explained by the regression model [30]. The prob $>$ F-value $(<0.05)$ expresses that model terms are significant, as well [30, 31]. The coefficient of variance (CV) (as the ratio of the standard error of estimated data to the mean value of the observed response) is a normative of the model reproducibility [30,32]. The adequate precision (AP) measures the signal to noise ratio ( $>4$ is desirable) and AP was compared for the range of the predicted values at the design points to the average prediction error [30, 31]. For the present research, signal to noise ratios were around 100.773 for COD. The adequacy of developed mathematical models to the experiment was examined by the diagnostic plots such as predicted plot versus actual one (Fig. 2(a)) and normal percent probability graphs (Fig. 2b). According to Fig. 2 (a) and (b), the actual values are very close to the predicted ones because actual values were distributed near the straight line. These plots state that there is a very good agreement between the observed data and the correlated ones obtained from the models. 
a)

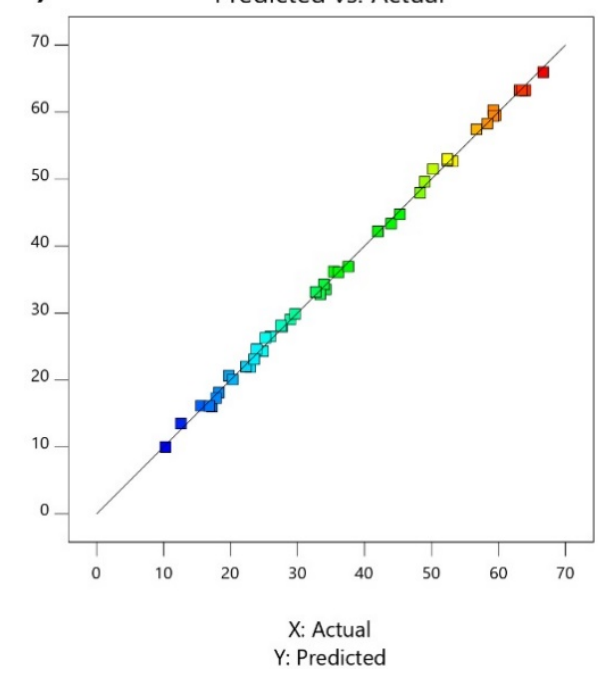

b) Normal Plot of Residuals

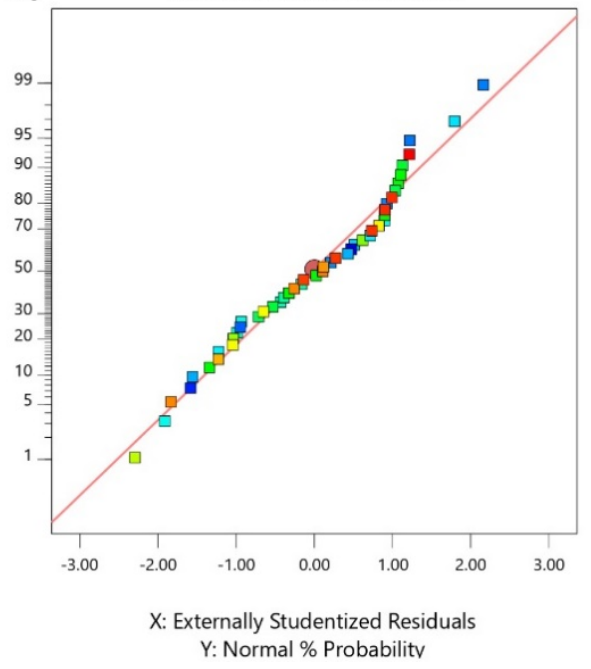

Fig. 2. (a) Predicted data versus actual ones, (b) Normal plot of residuals.

\section{Three dimensional plots for the regression model}

The effects of the independent variables on COD removal were graphically represented by three dimensional response surface plots (Fig. 3). The response surface plots are shown to visualize the effects of the experimental independent variables on the COD removal (as response). In fact, three dimensional plots show strong interaction between parameters and surfaces.

a)

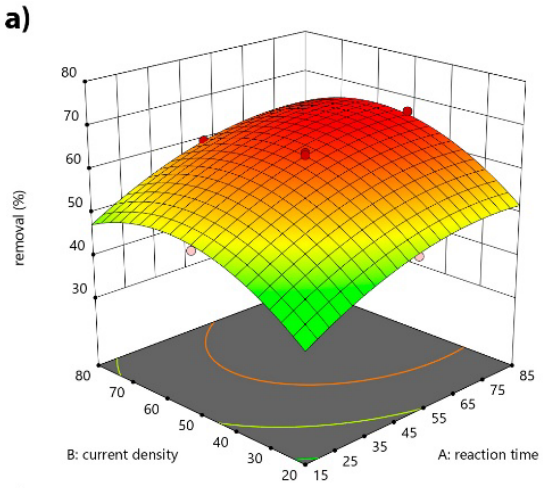

c)

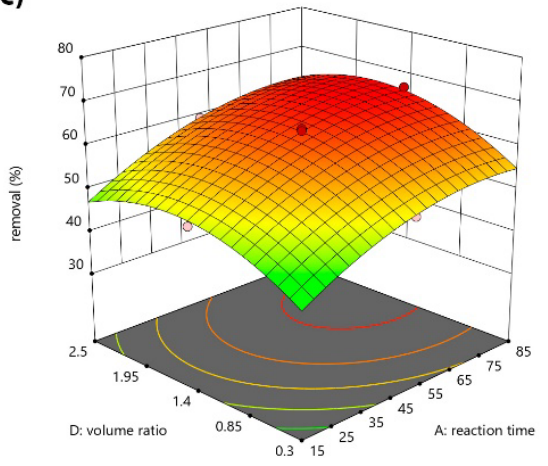

b)

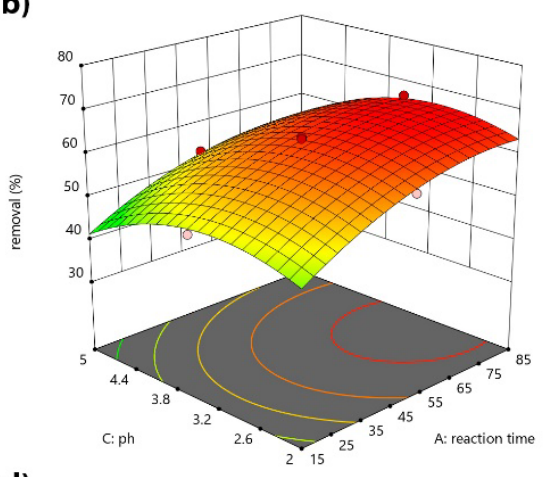

d)

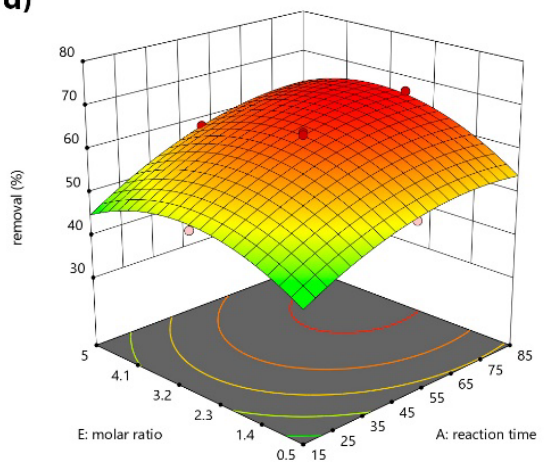


e)

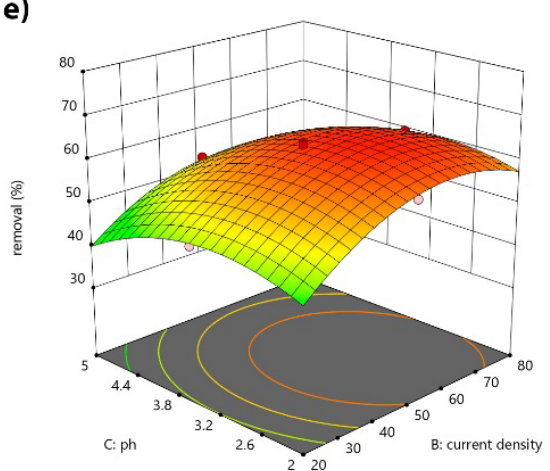

g)

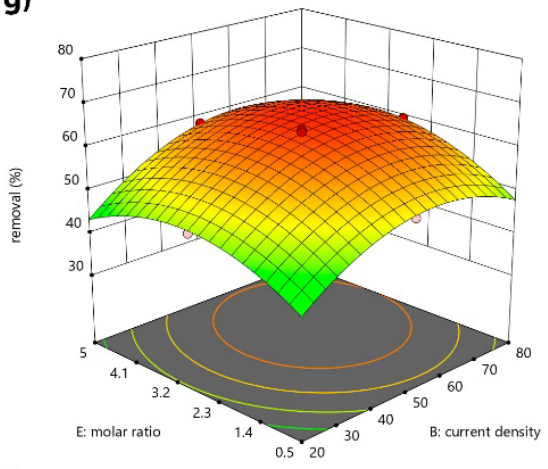

i)

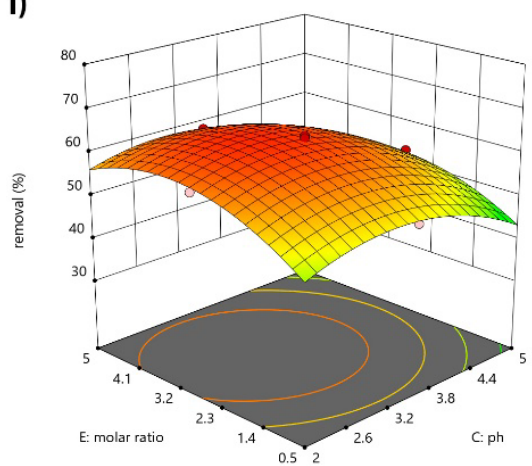

f)

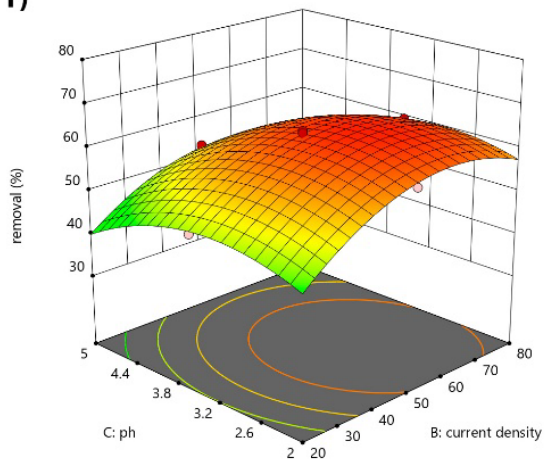

h)

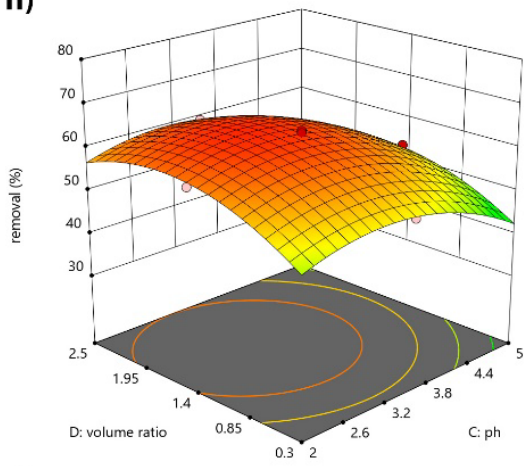

j)

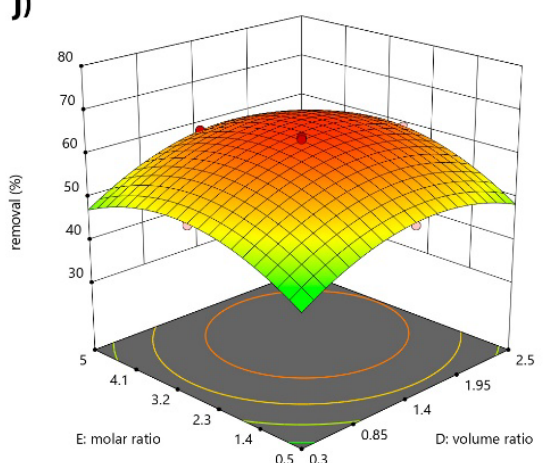

Fig. 3. Three-dimensional surface of COD removal (as a water quality sample) as a function: (a) reaction time and current density, (b) reaction time and $\mathrm{pH}$, (c) reaction time and $\mathrm{H}_{2} \mathrm{O}_{2} / \mathrm{CW}(\mathrm{mL} / \mathrm{L})$, (d) reaction time and $\mathrm{H}_{2} \mathrm{O}_{2} / \mathrm{Fe}^{2+}$, (e) current density and $\mathrm{pH}$, (f) current density and $\mathrm{H}_{2} \mathrm{O}_{2} / \mathrm{CW}(\mathrm{mL} / \mathrm{L})$, (g) current density and $\mathrm{H}_{2} \mathrm{O}_{2} / \mathrm{Fe}^{2+}$, (h) $\mathrm{pH}$ and $\mathrm{H}_{2} \mathrm{O}_{2} / \mathrm{CW}(\mathrm{mL} / \mathrm{L})$, (i) $\mathrm{pH}$ and $\mathrm{H}_{2} \mathrm{O}_{2} / \mathrm{Fe}^{2+}$, (j) $\mathrm{H}_{2} \mathrm{O}_{2} / \mathrm{CW}(\mathrm{mL} / \mathrm{L})$ and $\mathrm{H}_{2} \mathrm{O}_{2} / \mathrm{Fe}^{2+}$.

\section{Effect of pH}

The $\mathrm{pH}$ is one of the most important parameters for the EF process because it controls the hydroxyl radical formation [33]. In fact, hydroxyl radical formation can be expected to play a significant role during the EF reaction. The COD changes with $\mathrm{pH}$ are shown in Figs. 3(b), 3(e), 3(h) and 3(i). It affects the ferrous ions speciation and hydrogen peroxide decomposition. The ferrous ions precipitate when $\mathrm{pH}$ increases. In fact, it inhibits the ferrous ions regeneration. Therefore, the Fenton reaction rate decreases. Moreover, hydrogen peroxide cannot be decomposed to hydroxyl radical by $\mathrm{Fe}^{2+}$ when $\mathrm{pH}$ is less than two. It seems that hydrogen peroxide is changed to $\mathrm{H}_{3} \mathrm{O}_{2}{ }^{+}$by capturing one proton. Since $\mathrm{H}_{3} \mathrm{O}_{2}{ }^{+}$is an electrophilic compound, hydrogen 
peroxide and $\mathrm{Fe}^{2+}$ reaction rate will be decreased. The highest COD removal (66.67\%) was obtained at $\mathrm{pH}$ of 3.5 [34-37]. The Fenton's reaction in the bulk of solution was promoted when the produced hydrogen peroxide reacted with $\mathrm{Fe}^{2+}$. Furthermore, the hydroxyl radicals generated at the reaction increase $[34,38,39]$.

\section{Effect of current density}

The current density is directly related to COD removal. The effect of current density $\left(20-80 \mathrm{~A} / \mathrm{m}^{2}\right)$ on COD removal are shown in Figs. 3(a), 3(e) 3(f) and 3(g) [30,40]. The COD removal increases with increasing the current density. In fact, this is due to increasing ferrous ions regeneration from ferric ions at cathode in high current densities. It then enhances the Fenton reaction and increases the hydroxyl radical generation at the anode surface [41]. Moreover, the removal will be decreased after a certain point of current density. This may due to the competitive reactions in the cell. The oxygen production on anode and the hydrogen production on cathode occur at high current densities.

\section{Effect of reaction time}

The effect of reaction time on COD removal is shown in Figs. 3(a), 3(b), 3(c) and 3(d). The COD removal increases, and it reaches a maximum value of $66.67 \%$ at reaction time of $85 \mathrm{~min}$. It seems that the reaction time of $85 \mathrm{~min}$ is enough for the COD removal. This is due to large amount of hydrogen peroxide production which causes $\mathrm{H}_{2} \mathrm{O}_{2}$ decomposition to oxygen and water. Moreover, combination of hydroxyl radicals decreases their concentration in the solution [30].

\section{Effects of $\mathrm{H}_{2} \mathrm{O}_{2} / \mathrm{Fe}^{2+}$ molar ratio and volume ratio of $\mathrm{H2O} / \mathrm{CW}$}

According to Figs. 3(c), 3(f), 3(h) and 3(j), COD removal increased with $\mathrm{H}_{2} \mathrm{O}_{2}$ amount increment. On the other side, the molar ratio is a significant factor in the EF process which directly affects on the economical aspects of the process. Effects of $\mathrm{H}_{2} \mathrm{O}_{2} / \mathrm{Fe}^{2+}$ molar ratio on the COD removal are shown in Figs. 3(d), 3(g), 3(i) and $3(\mathbf{j})$. It can be observed that increasing the $\mathrm{H}_{2} \mathrm{O}_{2} / \mathrm{Fe}^{2+}$ molar ratio increases the amount of COD removal, as well [42].

As shown in these figures, hydroxyl radicals are decomposed by excessive hydrogen peroxide. In this side reaction, hydrogen peroxide and hydroxyl radical react and a weaker oxidant (hydroperoxyl radical) is produced (Eq. 7) [28,40].

$$
\mathrm{OH}^{\circ}+\mathrm{H}_{2} \mathrm{O}_{2} \rightarrow \mathrm{H}_{2} \mathrm{O}+\mathrm{HO}_{2}^{\circ}
$$

\section{Optimization and validation}

Numerical optimization was done to find the maximum value of COD and the other water quality parameters removal. The optimum conditions were statistically obtained at reaction time of $75.80 \mathrm{~min}$, current density of $58.81 \mathrm{~mA} / \mathrm{cm}^{2}, \mathrm{pH}$ of 3.02 , volume fraction of $\mathrm{H}_{2} \mathrm{O}_{2} / \mathrm{CW}$ of $1.62(\mathrm{ml} / \mathrm{l})$ and $\mathrm{H}_{2} \mathrm{O}_{2} / \mathrm{Fe}^{2+}$ molar ratio of 3.66 for $65.26 \%$ COD removal (predicted one). The optimized operating condition values for all water quality parameters were reported in Table 6, as well. Furthermore, the experimental data for validation of the optimization procedure were illustrated in Table 7. For example, for COD removal, the experimental percentage was around $68.72 \%$ (observed one) that was close to the predicted value with an error of $5 \%$. A very good agreement between experimental optimum data and statistical ones was observed. Moreover, the final treated wastewater $\mathrm{pH}$ was at 6.80 . 
Table 6. Optimized operating data obtained from the software for all water quality parameters.

\begin{tabular}{|c|c|c|c|c|c|}
\hline \multirow{2}{*}{$\begin{array}{c}\text { Water } \\
\text { quality } \\
\text { parameter }\end{array}$} & $\begin{array}{c}\text { Reaction } \\
\text { time } \\
(\mathbf{m i n})\end{array}$ & $\begin{array}{c}\text { Current } \\
\mathbf{d e n s i t y} \\
\left(\mathbf{m A} / \mathbf{c m}^{\mathbf{2}}\right)\end{array}$ & $\mathbf{p H}$ & $\begin{array}{c}\mathbf{H}_{2} \mathbf{O}_{2} / \mathbf{w a s t e w a t e r} \\
\mathbf{( m L / L )}\end{array}$ & $\begin{array}{c}\mathbf{H}_{2} \mathbf{O}_{2} / \mathbf{F e}^{\mathbf{2}} \\
\mathbf{m o l a r} \mathbf{r a t i o}\end{array}$ \\
\hline COD & 75.80 & 58.81 & 3.02 & 1.62 & 3.66 \\
\hline BOD $_{5}$ & 60.20 & 75.14 & 2.88 & 2.02 & 2.79 \\
\hline TOC & 80.05 & 66.12 & 3.56 & 1.25 & 3.65 \\
\hline TSS & 69.44 & 55.36 & 2.94 & 2.14 & 2.94 \\
\hline Heavy metals & 74.36 & 76.80 & 2.69 & 1.07 & 3.26 \\
\hline EC & 82.30 & 70.05 & 3.14 & 1.85 & 3.78 \\
\hline Surfactants & 68.88 & 61.55 & 3.66 & 1.53 & 2.80 \\
\hline Hardness & 78.66 & 44.14 & 3.00 & 1.66 & 3.60 \\
\hline
\end{tabular}

Table 7. Removal percentage values at the optimum conditions for all water quality parameters.

\begin{tabular}{ll}
\hline Water quality parameter & $\begin{array}{c}\text { Removal } \\
\text { percentage }\end{array}$ \\
\hline COD & 68.72 \\
BOD $_{5}$ & 75.13 \\
TOC & 66.89 \\
TSS & 71.75 \\
Heavy metals & 54.50 \\
EC & 60.14 \\
Surfactants & 73.56 \\
Hardness & 59.60 \\
\hline
\end{tabular}

\section{Conclusion}

The EF process as an efficient, simple and eco-friendly technique was proposed for the treatment of a real CW. However, the dissolved organic pollutants are mineralized in inorganic sludge during the electroFenton process and abundance of suspended solids facilitates the mineralization process but, formation of an impermeable film layer may reduce the reduction of $\mathrm{Fe}^{3+}$ on the cathode and reduce the process efficiency. ANOVA showed good coefficient of determination values $\left(\mathrm{R}^{2}>0.99\right)$ for the correlation. According to the analysis, reaction time had a very significant effect on the COD removal. Since CW COD reduced to 143.88 $\mathrm{mg} / \mathrm{L}$ (at the optimum conditions), a series of EF process or another supplementary treatment (applicable for lower COD values such as biological treatment) is requested for lower COD values than this however it properly satisfies the environmental standards.

\section{References}

1. Distefano, T.; Kelly, S. Ecological Economics 2017, 142, 130-147.

2. Zhan, Y.; Wan, X.: He, S.: Yang, Q.; He, Y. Chemical Engineering Journal 2018, 333, 132-145.

3. Panizza, M.; Cerisola, G. Journal of Electroanalytical Chemistry 2010, 638, 28-32. 
4. Kim, S.; Chu, K.H.; Al-Hamadani, Y.A.J.; Park, C.M.; Jang, M.; Kim, D-H.; Yu, M.; Heo, J.; Yoon, Y. Chemical Engineering Journal 2018, 335, 896-914.

5. Zietzschmann, F.; Stützer, C.; Jekel, M.; Water Research 2016, 92, 180-187.

6. Zietzschmann, F.; Altmann, J.; Hannemann, C.; Jekel, M. Water Research 2015, 83, 52-60.

7. Liu, C-H.; Wu, J-S.; Chiu, H-C.; Suen, S-Y.; Chu, K.H. Water Research 2007, 41, 1491-1500.

8. Panizza, M.; Cerisola, G Journal of Electroanalytical Chemistry 2010, 638, 236-240.

9. Zaneti, R.; Etchepare, R.; Rubio, J. Resources, Conservation and Recycling 2011, 55, 953-959.

10. Pinto, A.C.S.; de Barros Grossi, L.; de Melo, R.A.C.; de Assis, T.M.; Ribeiro, V.M.; Amaral, M.C.S.; de Souza Figueiredo, K.C. Journal of Water Process Engineering 2017, 17, 143-148.

11. Magnago, R.F.; Berselli, D.; Medeiros, P. Journal of Engineering Science and Technology 2018, 13,838-50.

12. Lee, H.; Shoda, M. Journal of Hazardous Materials 2008, 153, 1314-1319.

13. Golbaz, S.; Jonidi Jafari, A.; Rezaei Kalantari, R. Iranian Journal of Health and Environment 2013, $5,423-432$.

14. Ghoneim, M.M., El-Desoky, H.S.; Zidan, N.M. Desalination 2011, 274, 22-30.

15. Karimi, A.; Mahdizadeh, F.; Eskandarian, M. Chemical Industry and Chemical Engineering Quarterly/CICEQ 2012, 18, 89-94.

16. Gençten, M.; Özcan, A. Chemosphere 2015, 136, 167-173.

17. Loaiza-Ambuludi, S.; Panizza, M.; Oturan, N.; Özcan, A.; Oturan, M.A. Journal of Electroanalytical Chemistry 2013, 702, 31-36.

18. Khataee, A.; Vatanpour, V.; Ghadim, A.A. Journal of Hazardous Materials 2009, 161, 1225-1233.

19. Mohanty, N.R.; Wei, I.W. Hazardous Waste and Hazardous Materials 1993, 10, 171-183.

20. Safarzadeh-Amiri, A.; Bolton, J.R.; Cater, S.R. Journal of Advanced Oxidation Technologies 1996, 1, 18-26.

21. Atmaca, E. Journal of Hazardous Materials 2009, 163, 109-114.

22. Nidheesh, P.V.; Gandhimathi, R. Desalination 2012, 299, 1-15.

23. Rosales, E.; Pazos, M.; Sanroman, M.A. Chemical Engineering \& Technology 2012, 35, 609-617.

24. Davarnejad, R.; Sabzehei, M. Separation Science and Technology 2018, 4,1-0.

25.Zhang, H.; Jin Choi, H.; Canazo, P.; Huang, C.P. Journal of Hazardous Materials 2009, 161, 13061312.

26. Virkutyte, J.; Rokhina, E.; Jegatheesan, V. Bioresource Technology 2009, 101, 1440-1446.

27. Kabuk, H.A.; İlhan, F.; Avsar, Y.; Kurt, U.; Apaydin, O.; Gonullu, M.T. CLEAN - Soil, Air, Water 2013, 42, 571-577.

28. Davarnejad, R.; Nikseresht, M. Journal of Electroanalytical Chemistry 2016, 775, 364-373.

29. El-Ghenymy, A.; Garcia-Segura, S.; Rodríguez, R.M.; Brillas, E.; El Begrani, M.S.; Abdelouahid, B.A. Journal of Hazardous Materials 2012, 221-222, 288-297.

30. Davarnejad, R.; Mohammadi, M.; Ismail, A.F. Journal of Water Process Engineering 2014, 3, 18-25.

31. Ghaemi, N.; Zereshki, S.; Heidari, S. Process Safety and Environmental Protection 2017, 111,475-90.

32. Körbahti, B.K.; Aktaş, N.; Tanyolaç, A. Journal of Hazardous Materials 2007, 148, 83-90.

33. Babuponnusami, A.; Muthukumar, K. Separation and Purification Technology 2012, 98, 130-135.

34. Jiang, C-c.; Zhang, J-f. Journal of Zhejiang University-SCIENCE A 2007, 8, 1118-1125.

35. Nidheesh, P.; Gandhimathi, R. Desalination 2012, 299, 1-15.

36. Mohajeri, S.; Aziz, H.A.; Isa, M.H.; Zahed, M.A.; Adlan, M.N. Journal of Hazardous Materials 2010, 176, 749-758.

37. Badawy, M.I.; Ali, M. Journal of Hazardous Materials 2006, 136, 961-966.

38. Babuponnusami, A.; Muthukumar, K. CLEAN - Soil, Air, Water 2011, 39, 142-147.

39. Buxton, G.V.; Greenstock, C.L.; Helman, W.P.; Ross, A.B. Journal of Physical and Chemical Reference Data 1998, 17, 513-886.

40. Davarnejad, R.; Sahraei, A. Desalination and Water Treatment 2016, 57, 9622-9634.

41. Moussavi, G.; Aqanaghad, M. Sustain Environ Res 2015, 25, 249-254.

42. He, J.; Yang, X.; Men, B.; Yu, L.; Wang, D. Journal of Molecular Catalysis A: Chemical 2015, 408, 179-188. 